\title{
CANDIES IN MIXED MASS OF GUAVA AND MANGO TYPE MARIOLA: DEVELOPMENT AND CHARACTERIZATION
}

Doce em massa misto de goiaba e manga tipo mariola: desenvolvimento e caracterização

Dulces en masa mixta de guava y mango tipo mariola: desarrollo y caracterización

\section{Antônia Maria Luiza de Oliveira Germano ${ }^{1}$, Emanuel Neto Alves de Oliveira ${ }^{2}$, Bruno Fonsêca Feitosa $^{* 3}$, Wisla Kívia de Araújo Soares ${ }^{4}$, Francisco Lucas Chaves Almeida ${ }^{5}$}

${ }^{1}$ Técnica em Alimentos, Instituto Federal do Rio Grande do Norte, Pau dos Ferros, RN, Brasil.

${ }^{2}$ Docente do Curso Técnico em Alimentos, Instituto Federal do Rio Grande do Norte, Pau dos Ferros, RN, Brasil.

${ }^{3}$ Graduando em Engenharia de Alimentos, Universidade Federal de Campina Grande, Pombal, PB, Brasil.

${ }^{4}$ Engenheira de Alimentos, Universidade Federal de Campina Grande, Pombal, PB, Brasil.

${ }^{5}$ Doutorando em Bioenergia, Universidade Estadual de Campinas, Campinas, SP, Brasil.

*Correspondência: Universidade Federal de Campina Grande, Jairo Vieira Feitosa 1770, Pombal, Paraíba, Brasil. CEP: 58840-000.E-mail: brunofonsecafeitosa@live.com

Artigo recebido em 07/08/2020 aprovado em 03/12/2020 publicado em 08/06/2021.

\section{RESUMO}

Os desperdícios de frutas são minimizados com a elaboração de diferentes tipos de doces. Os doces em massa podem ser enriquecidos nutricionalmente pela mistura de frutas, como goiaba e manga. Assim, objetivou-se desenvolver doces em massa misto de goiaba e manga tipo mariola, bem como avaliar as características físico-químicas e aceitação sensorial. Foram elaborados três doces em massa, diferenciados pelas concentrações de polpa de goiaba e manga. Analisou-se as características físico-químicas, aceitação sensorial, Índice de Aceitabilidade, Aceitabilidade Geral e intenção de compra. Os dados obtidos foram tratados com Análise de Variância, em Delineamento Inteiramente Casualizado, comparando-se as médias pelo teste de Tukey a 5\% de significância. Os doces atenderam aos padrões de identidade e qualidade preconizados pela legislação brasileira. Somente os valores de $\mathrm{pH}$ não diferiram significativamente, variando entre 3,92 e 3,97. Os doces apresentaram no atributo consistência uma variação dos termos entre "gostei muito" e "gostei muitíssimo". A formulação com 30\% goiaba e $20 \%$ manga destacou-se como mais bem aceita. A elaboração de doces de goiaba e manga tipo mariola pode ser viável e são bem aceitos sensorialmente.

Palavras-chave: Aceitação sensorial. Doce de frutas. Mangifera indica L. Mariolas. Psiduim guajava L.

\section{ABSTRACT}

Fruit waste is minimized by making different types of candies. The mass in mass can be nutritionally enriched by mixing fruits, such as guava and mango. Thus, the objective was to develop candies in mixed mass of guava and mango type mariola, as well to evaluate the physical-chemical characteristics and sensory acceptance. Three candies in mass were made, differentiated by the concentrations of guava and mango pulp. The physical-chemical characteristics, sensory acceptance, Acceptability Index, General Acceptability and buy intention were analyzed. The data obtained were treated with Analysis of Variance, in a Completely Randomized Design, comparing the means 
by the Tukey test at 5\% significance. The candies met the standards of identity and quality recommended by Brazilian legislation. Only the $\mathrm{pH}$ values did not differ significantly, varying between 3.92 and 3.97. The candies presented a variation of terms in the consistency attribute between "I liked it a lot" and "I liked it a very much". The formulation with 30\% guava and $20 \%$ mango stood out as the best accepted. The preparation of guava and mango type candies can be feasible and are well-accepted sensorially.

Keywords: Sensory acceptance. Fruit candy. Mangifera indica L. Mariolas. Psidium guajava L.

\section{RESUMEN}

El desperdicio de fruta se minimiza al hacer diferentes tipos de dulces. Los dulces a pasta pueden enriquecerse nutricionalmente al mezclar frutas, como la guayaba y el mango. Por lo tanto, el objetivo era desarrollar dulces mixta en pasta de mariola tipo guayaba y mango, así como evaluar las características físico-químicas y la aceptación sensorial. Se prepararon tres dulces pasta, diferenciados por las concentraciones de pulpa de guayaba y mango. Se analizaron las características físico-químicas, la aceptación sensorial, el Índice de Aceptabilidad, Aceptabilidad General e intención de compra. Los datos obtenidos se trataron con Análisis de varianza, en un diseño completamente al azar, comparando las medias mediante la prueba de Tukey con una significancia del 5\%. Los dulces cumplieron con los estándares de identidad y calidad recomendados por la legislación brasileña. Solo los valores de pH no difirieron significativamente, variando entre 3.92 y 3.97. Los dulces presentaron una variación de términos en el atributo de consistencia entre "Me gustó muy" y "Me gustó mucho". La formulación con 30\% de guayaba y $20 \%$ de mango se destacó como la más aceptada. La preparación de dulce mariola de guayaba y mango puede ser factible y bien aceptada sensorialmente.

Descriptores: Aceptación sensorial. Dulces de frutas. Mangifera indica L. Mariolas. Psiduim guajava L.

\section{INTRODUCTION}

In Brazil, the fruit growing presents an important social and economic activity. It is estimated that at around $53 \%$ of all national fruits production is destined for processing. The Northeast, despite the water limitations, is responsible for $27 \%$ of this total, highlighting the cultivation of coconut, guava, papaya, mango, passion fruit, pineapple and melon (ARAÚJO et. al., 2014; VIDAL; XIMENES, 2016).

Guava (Psidium guajava L.) is a typical fruit of tropical and subtropical regions. Brazil stands out by economical representativeness and intense consumption of in natura and processed guava. This fruit has a nutritional intake that is based in exogenous antioxidants, such as vitamin $\mathrm{C}$, carotenoids, phenolic compounds and flavonoids (AMORIM et al., 2015; ARAÚJO et al., 2015; SILVA et al., 2016).

Mango (Mangifera indica L.) is a fruit with nutritional quality, that is compound by bioactive, such as vitamin $\mathrm{C}$ and carotenoids, responsible by health promotion (MELO; ARAÚJO, 2011; SOARES; JOSE, 2013). Due to grown of several regions of the world, its economic importance and exportation potential are high (ONIAS et al., 2016).

It is known that fruit candies production cab be an agroindustrial activity able to aggregate economical value to in natura raw material, besides that to enable the waste minimization during the commercialization. Mixed formulations have prepared with the aim of enriching nutritionally products already exist in the market (VALIM, 2011; MOURA et al., 2014).

In Brazilian legislation, candies in mass can be called cut type candies. More intensely in recent years, the commercialization of mariola type candies has grown (BRASIL, 2005; OLIVEIRA et al., 2018). These candies are elaborate by the cooking of vegetables or edible parts of crumbled vegetables and sugar, pectin, and organic acids to $\mathrm{pH}$ setting (BRASIL, 1978; 2005). 
Candies mariola type can be classified as simple or mixed, when in the formulation there is only one vegetable specie and when in the formulation there is more one vegetable specie, respectively (OLIVEIRA et al., 2018). However, there weren't found in the literature results in candies in mixed mass type mariola.

Thus, this work aims to develop candies in mixed mass of guava and mango type mariola, as well to evaluate the physical-chemical characteristics and sensory acceptance.

\section{MATERIAL AND METHODS}

This study was developed at the Federal Institute of Education, Science and Technology of Rio Grande do Norte, campus Pau dos Ferros-RN. Ingredients used were commercial sugar, pectin of high methoxylation content - HMC (Genu® of $\mathrm{CP}$ Kelco) and in natura fruits (guava and mango), bought in the local businesses of Pau dos Ferros-RN.

Fruits have submitted the steps of maturation stage selection mature, sanitization with the chlorinated solution (100 ppm/10 min), rinsing, peeling, separating the seeds from the mangoes, cutting, grinding in an industrial blender and filtering through nylon sieves to separate the guava seeds. Thus, the Guava Pulps (GP) and Mango Pulps (MP) were prepared.

Through preliminary tests and according to the methodology described by Oliveira Neto et al. (2018), it was defined three formulations of candies in mixed mass of guava and mango type mariola. These candies are different in the concentrations of GP and MP, being $\mathrm{M}_{1}$ (25\% de GP e $25 \%$ de MP), $\mathrm{M}_{2}$ (20\% de GP e $30 \%$ de MP) e $\mathrm{M}_{3}$ (30\% de GP e $20 \%$ de MP). In Table 1 are detailed the formulations.

For the preparation of candies, the solid ingredients were mixed and, then, with the pasty, respectively. The mixture was subjected to the cooking process in stainless steel pots up to a Total Soluble
Solids content (TSS) of $74^{\circ}$ Brix (reading in a manual refractometer), according to the methodology described by the Adolfo Lutz Institute (ALI, 2008).

Table 1. Formulations of candies in mixed mass of guava and mango type mariola.

\begin{tabular}{cccc}
\hline \multirow{2}{*}{ Ingredients (\%) } & \multicolumn{3}{c}{ Formulations } \\
\cline { 2 - 4 } & $\mathrm{M}_{1}$ & $\mathrm{M}_{2}$ & $\mathrm{M}_{3}$ \\
\hline Guava Pulp (GP) & 25 & 20 & 30 \\
Mango Pulp (MP) & 25 & 30 & 20 \\
Sugar & 48 & 48 & 48 \\
Pectin of HMC & 2 & 2 & 2 \\
\hline
\end{tabular}

Subsequently, the candies were added while still hot in polyethylene trays, previously sanitized. When the products reached room temperature, they were cut into small tablets $(3 \times 5 \mathrm{~cm})$, which were subjected to granulation with crystal sugar. Then, the candies were placed in polyethylene pots with a capacity of $200 \mathrm{~mL}$ and stored at room temperature.

The physical-chemical characteristics of the candies were evaluated, in triplicate, regarding the parameters: water content (drying in an oven, at 105 ${ }^{\circ} \mathrm{C} / 24 \mathrm{~h}$ ); $\mathrm{pH}$ (direct reading in pHmeter); Total Titratable Acidity - TTA (titration with $0.1 \mathrm{~N} \mathrm{NaOH}$ ); TSS; Total Reducing Sugars - TRS, Non-Reducing Sugars - NRS, Total Sugars - TS (Lane-eynon method); and Ratio, through the TSS/TTA relationship (ALI, 2008). The water activity $\left(A_{w}\right)$ of the candies was evaluated using digital equipment (Aqualab®, model Labstart).

The sensory analysis of the candies in mixed mass of guava and mango type mariola was carried out with 50 untrained evaluators. The sensorial acceptance of the attributes color, appearance, aroma, consistency, flavor, sweetness and overall impression was evaluated, using a hedonic scale of nine points, being 1 - extremely disliked, 2 - disliked a lot, 3 - dislodged moderately, 4 - dislocated slightly, 5 - neither liked nor disliked, 6 - I liked it slightly, 7 - I liked it moderately, 8 - I liked it a lot and 9 - I liked it a very much (DUTCOSKY, 2013). 
The Acceptability Index (AI) and the General Acceptability were calculated, according to Gularte (2009). The buy intention was analyzed using a fivepoint hedonic scale, being 1 - would certainly not buy the product, 2 - probably would not buy the product, 3 - maybe bought/ maybe didn't buy, 4 - would probably buy the product 5 - would certainly buy the product (DUTCOSKY, 2013).

The data obtained in the physical-chemical and sensory analyzes were analyzed with the aid of the software Assistat version 7.7 beta (SILVA; AZEVEDO, 2016). An Analysis of Variance (ANOVA) was applied, in a Completely Randomized Design (CRD), comparing the means by the Tukey test at $5 \%$ significance level $(\mathrm{p}<0.05)$.

\section{RESULTS AND DISCUSSION}

Table 2 presents the results of the physicalchemical analysis of the candies in mixed mass of guava and mango type mariola.

Table 2. Physical-chemical analysis of the candies in mixed mass of guava and mango type mariola.

\begin{tabular}{ccccc}
\hline \multirow{2}{*}{ Parameters } & \multicolumn{3}{c}{ Candies in mixed mass type } \\
& \multicolumn{3}{c}{ mariola } & SMD \\
\cline { 2 - 4 } & $\mathrm{M}_{1}$ & $\mathrm{M}_{2}$ & $\mathrm{M}_{3}$ & \\
\hline Water content $(\%)$ & $22.88^{\mathrm{a}}$ & $17.52^{\mathrm{b}}$ & $19.34^{\mathrm{b}}$ & 2.36 \\
$\mathrm{~A}_{\mathrm{w}}$ & $0.67^{\mathrm{a}}$ & $0.61^{\mathrm{b}}$ & $0.61^{\mathrm{b}}$ & 0.01 \\
pH & $3.92^{\mathrm{a}}$ & $3.97^{\mathrm{a}}$ & $3.93^{\mathrm{a}}$ & 0.06 \\
TTA (\%) & $0.58^{\mathrm{a}}$ & $0.46^{\mathrm{b}}$ & $0.29^{\mathrm{c}}$ & 0.08 \\
TSS ( ${ }^{\mathrm{o}}$ Brix) & $74.00^{\mathrm{b}}$ & $77.00^{\mathrm{a}}$ & $74.00^{\mathrm{b}}$ & 0.01 \\
Ratio & $128.47^{\mathrm{c}}$ & $169.10^{\mathrm{b}}$ & $256.88^{\mathrm{a}}$ & 3.81 \\
TRS (\%) & $13.36^{\mathrm{c}}$ & $14.53^{\mathrm{b}}$ & $15.75^{\mathrm{a}}$ & 0.76 \\
NRS (\%) & $37.65^{\mathrm{b}}$ & $48.27^{\mathrm{a}}$ & $37.50^{\mathrm{b}}$ & 1.41 \\
TS (\%) & $53.00^{\mathrm{c}}$ & $65.34^{\mathrm{a}}$ & $55.22^{\mathrm{b}}$ & 1.66 \\
\hline
\end{tabular}

Guava Pulps (GP), Mango Pulps (MP), $\mathrm{M}_{1}(25 \%$ GP and $25 \%$ MP), $\mathrm{M}_{2}$ (20\% GP and 30\% MP) and $\mathrm{M}_{3}$ (30\% GP and 20\% MP). Water activity $\left(\mathrm{A}_{\mathrm{w}}\right)$, Total Titratable Acidity (TTA), Total Soluble Solids (TSS), Total Reducing Sugars (TRS), Non-Reducing Sugars (NRS), Total Sugars (TS) and Significant Mean Deviation (SMD). Significant Average Deviation (SAD). Means followed in line by the same letter do not differ significantly by Tukey test at $5 \%$ significance.

Results show high water content to $\mathrm{M}_{1}$, with a significative difference $(\mathrm{p}<0.05)$ if compared to the other formulations. Most of the values are probably related to the composition of the raw material used. Relating the $A_{w}, M_{1}$ showed the highest value, with
0.67. There wasn't a significant difference $(\mathrm{p}<0.05)$ between $\mathrm{M}_{2}$ and $\mathrm{M}_{3}$. Low values of $\mathrm{A}_{\mathrm{w}}$ in the products can limit the microorganism's multiplications and biochemistry reactions.

The $\mathrm{pH}$ values were statistically equal $(\mathrm{p}<0.05)$, from $3.92\left(\mathrm{M}_{1}\right)$ to $3.97\left(\mathrm{M}_{2}\right)$. Hence, different concentrations of GP and MP didn't modify this parameter. According to Moura et al. (2014), when candies $\mathrm{pH}$ is more than 4.5 , pathogenic bacteria are favored, for example, the Clostridium botulinum. In this study, Moura et al. (2014) found similar $\mathrm{pH}$ values, among 3.79 and 4.16, when they studied creamy guava candy.

The TTA values showed a significant difference $(p<0.05)$ between each other. $M_{1}$ formulation presented higher acidity (0.58\%) than others. In this study, could be seen that the greater the amount of GP the lower the total acidity of the products, probably due to the higher concentration of organic acids in this fruit.

It could be seen the variation from $74.00\left(\mathrm{M}_{1}\right.$ and $\left.\mathrm{M}_{3}\right)$ to $77.00{ }^{\circ} \mathrm{Brix}\left(\mathrm{M}_{2}\right)$ for TSS values, there weren't significative difference $(\mathrm{p}<0.05)$ between $\mathrm{M}_{1}$ and $M_{3}$. The Normative Resolution $\mathrm{n}^{\circ} 9$ of 1978 , recommends that the TSS values for candies in mass should be greater than $65{ }^{\circ}$ Brix (BRASIL, 1978). Hence, all candies produced obtained results by followed per under legislation.

The Ratio level is the relation between TSS/TTA, and this can indicate the sweetness sensation of products. It was observed significative difference $(\mathrm{p}<0.05)$ among candies, being that $\mathrm{M}_{1}$ formulation showed the lowest value (128.47) and $\mathrm{M}_{3}$ formulation the highest value (256.88). So, different concentrations of GP can influence this parameter, so that the higher GP quantity higher the Ratio products. Santana Neto et al. (2014) obtained higher Ratio results, among 291.41 and 400.14, when they studied banana candies in mass. 
In the sugar levels occurred significative difference $(\mathrm{p}<0.05)$ among candies for all parameters, except for $\mathrm{M}_{1}$ and $\mathrm{M}_{3}$ for NRS. The values varied from13.36 $\left(\mathrm{M}_{1}\right)$ to $15.75 \%\left(\mathrm{M}_{3}\right)$, and it could see the GP influence. By following per under Dias et al. (2011), sucrose inversion to reducing sugars is desirable in the proportion greater than $30 \%$, aimed at crystallization prevention because of the increase the sucrose solubility during the storage. In this work, candies in mixed mass of guava and mango type mariola $\mathrm{M}_{2}$ (20\% of GP and $30 \%$ of MP) showed a higher level of TA than other formulations. Oliveira Neto et al. (2018) got higher TA levels when they studied banana candies in mass (77.99\%), reducing the sugar levels with banana pell addition.

In Table 3 are results got the acceptance of sensory attributes and Acceptability Indexes (AI) of the candies in mixed mass of guava and mango type mariola.

Table 3. Sensory attributes acceptance and Acceptability Indexes of the candies in mixed mass of guava and mango type mariola.

\begin{tabular}{ccccc}
\multicolumn{4}{c}{ type mariola. } \\
\cline { 2 - 4 } Attributes & \multicolumn{2}{c}{$\begin{array}{c}\text { Candies in mixed mass } \\
\text { type mariola }\end{array}$} & \multirow{2}{*}{ SMD } \\
\cline { 2 - 4 } & $\mathrm{M}_{1}$ & $\mathrm{M}_{2}$ & $\mathrm{M}_{3}$ & \\
\hline Color & $7.88^{\mathrm{a}}$ & $8.18^{\mathrm{a}}$ & $8.34^{\mathrm{a}}$ & \multirow{2}{*}{0.48} \\
AI $(\%)$ & 87.55 & 90.88 & 92.66 & \\
Appearance & $7.86^{\mathrm{b}}$ & $8.14^{\mathrm{ab}}$ & $8.36^{\mathrm{a}}$ & \multirow{2}{*}{0.49} \\
AI $(\%)$ & 87.33 & 90.44 & 92.88 & \\
Aroma & $7.76^{\mathrm{a}}$ & $8.16^{\mathrm{a}}$ & $8.08^{\mathrm{a}}$ & \multirow{2}{*}{0.47} \\
AI $(\%)$ & 86.22 & 90.66 & 89.77 & \\
Consistency & $8.04^{\mathrm{a}}$ & $8.16^{\mathrm{a}}$ & $8.12^{\mathrm{a}}$ & \multirow{2}{*}{0.53} \\
AI $(\%)$ & 89.33 & 90.66 & 90.22 & \\
Taste & $7.74^{\mathrm{a}}$ & $8.22^{\mathrm{a}}$ & $8.12^{\mathrm{a}}$ & \multirow{2}{*}{0.60} \\
AI $(\%)$ & 86.00 & 91.33 & 90.22 & \\
Sweetness & $7.96^{\mathrm{a}}$ & $8.14^{\mathrm{a}}$ & $7.92^{\mathrm{a}}$ & \multirow{2}{*}{0.59} \\
AI $(\%)$ & 88.44 & 90.44 & 88.00 & \\
AI $(\%)$ & $7.94^{\mathrm{a}}$ & $8.18^{\mathrm{a}}$ & $8.34^{\mathrm{a}}$ & \multirow{2}{*}{0.47} \\
Overall Impression & 88.22 & 90.88 & 92.66 & \\
\hline
\end{tabular}

Guava Pulps (GP), Mango Pulps (MP), $\mathrm{M}_{1}(25 \%$ GP and $25 \%$ $\mathrm{MP}), \mathrm{M}_{2}$ (20\% GP and 30\% MP) and $\mathrm{M}_{3}$ (30\% GP and 20\% MP). Acceptability Index (AI) and Significant Mean Deviation (SMD). Means followed on the line by the same letter do not differ significantly by Tukey test at $5 \%$ significance.

Color, aroma, consistency, taste, sweetness, and overall impression results didn't show the significative difference $(\mathrm{p}<0.05)$ among candies. The average of all attributes, with consistency exception, was between "I liked it moderately" and "I liked it a very much", using the hedonic terms, with AI greater than $85 \%$. By following Gularte (2009), the product is considered to accept if it has $\mathrm{AI} \geq 70 \%$.

Regarding the concerning the appearance attribute, there wasn't significative difference $(\mathrm{p}<0.05)$ among $\mathrm{M}_{2}$ and other formulations. In this attribute, the average varied from "I liked it moderately" and "I liked it a very much", with results greater for $\mathrm{M}_{3}$, with $30 \%$ of GP and $20 \%$ of MP. Godoy et al. (2014) found less sensory acceptance for appearance (between 5.0 and 5.7), studying cut type banana candy.

The candies presented the average consistency of notes in hedonic terms, varying between "I liked it a lot" and "I liked it a lot". This attribute can be associated with TSS of formulations, important for the gel formation, and reaching the correct candies point. Consistency's AI was between $89.33\left(\mathrm{M}_{1}\right)$ and $90.66 \%$ $\left(\mathrm{M}_{2}\right)$ which is considered a positive value to marketing tests, by following per under Gularte (2009). The greatest AI was seen in the attributes color, appearance, and overall impression, mainly in the $\mathrm{M}_{3}$ formulation, that has the greatest GP concentration.

General Acceptability Indexes are presented in Figure 1 of the candies in mixed mass of guava and mango type mariola.

Figure 1. General Acceptability of the candies in mixed mass of guava and mango type mariola.

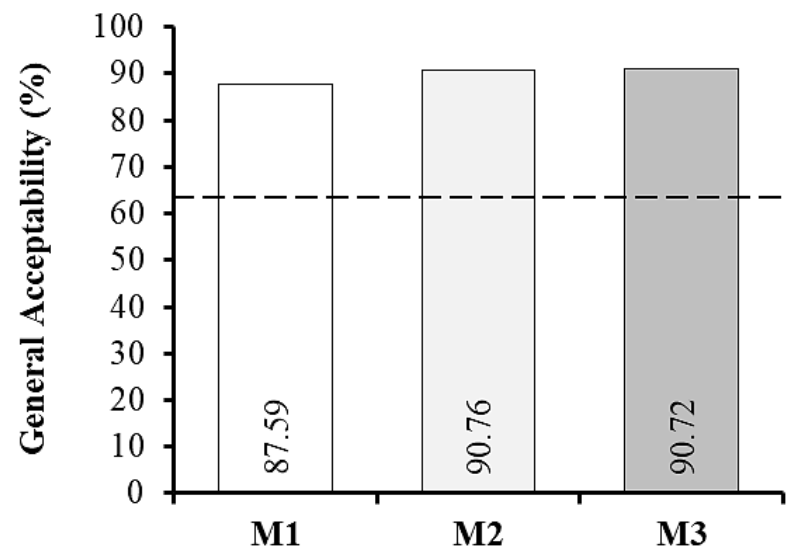


About to with concerning General Acceptability was found values greatest than $70 \%$. It is known, by following per under Gularte (2009), the AI minimum of $70 \%$ is considered for the product will be accepted relating its sensory properties.

The $\mathrm{M}_{3}$ got General Acceptability of $90.92 \%$ highlighting if compared with the other formulations. Campos et al. (2015) found superior results the $70 \%$ when studied candies in mass of passion fruit and guava (from 83.80 to $86.00 \%$ ), Kato et al. (2013) also found superior results the $70 \%$ being it $84.30 \%$ of General Acceptability, when studied pumpkin candy with coconut.

In Table 4 are results got the buy intention of the candies in mixed mass of guava and mango type mariola.

Table 4. Buy intention of the candies in mixed mass of guava and mango type mariola.

\begin{tabular}{ccc}
\hline $\begin{array}{c}\text { Candies in mixed } \\
\text { mass type mariola }\end{array}$ & Buy intention & SMD \\
\hline $\mathrm{M}_{1}$ & $4,12^{\mathrm{b}}$ & \\
$\mathrm{M}_{2}$ & $4,34^{\mathrm{ab}}$ & 0,36 \\
$\mathrm{M}_{3}$ & $4,54^{\mathrm{a}}$ & \\
\hline
\end{tabular}

Guava Pulps (GP), Mango Pulps (MP), M 1 (25\% GP and 25\% $\mathrm{MP}), \mathrm{M}_{2}(20 \% \mathrm{GP}$ and $30 \% \mathrm{MP})$ and $\mathrm{M}_{3}(30 \% \mathrm{GP}$ and $20 \% \mathrm{MP})$. Significant Mean Deviation (SMD). Means followed in line by the same letter do not differ significantly by Tukey test at 5\% significance.

In the intention buy the candies, a variation of the hedonic terms was found between "would probably buy the product" and "would certainly buy the product". There were no significant differences $(\mathrm{p}<0.05)$ between candy $\mathrm{M}_{2}$ and the others, with a higher average for the $\mathrm{M}_{3}$ formulation (4.54). It is possible due to the higher overall AI (Figure 1), Ratio content (Table 2), and GP concentration.

Guava candy (goiabada) is more commonly found in commerce, so it probably has a higher consumption by consumers. Diógenes-Júnior et al. (2019), when evaluating soursop dough candy, obtained an average variation of the hedonic terms between "maybe bought/ maybe didn't buy" and "would certainly buy the product".

\section{CONCLUSION}

The candies in mixed mass of guava and mango type mariola met the standards of identity and quality recommended by Brazilian legislation, with low levels of water activity, which tend to limit changes during storage. The different concentrations of guava and mango pulp were significant factors, mainly for the values of total acidity and Ratio.

In the sensorial acceptance of the candies, high Acceptability Indexes and buy intention were observed, highlighting the most accepted formulation, with $30 \%$ guava pulp and $20 \%$ mango pulp. Therefore, the elaboration of mixed masses of guava and mango type mariola can be viable and well accepted, with different sensory attributes and nutritional value.

All authors have declared that there is no potential conflict of interest regarding this article.

\section{REFERENCES}

ALI. Adolfo Lutz Institute. Physico-chemical methods for food analysis. 4th ed., 1st ed. Digital, São Paulo, 2008. 1020p.

AMORIM, D. A.; ROZANE, D. E.; SOUZA, H. A.; MODESTO, V. C.; NATALE, W. Nitrogen and potassium fertilization in 'Paluma' guava trees: Effect on productivity and fruit quality for industrialization.

Revista Brasileira de Fruticultura, v. 37, n. 1, p. 201-209, 2015.

ARAÚJO, H. M.; RODRIGUES, F. F. G.; COSTA, W. D.; NONATO, C. F. A.; RODRIGUES, F. F. G.; BOLIGON, A. A.; ATHAYDE, M..; COSTA, J. G. M. Chemical profile and antioxidant capacity verification of Psidium guajava (Myrtaceae) fruits at different stages of maturation. EXCLI Journal, Dortmund, v. 14, p. 1020-1030, 2015.

ARAÚJO, K. L. G. V.; MAGNANI, M.; NASCIMENTO, J. A.; SOUSA, A. L.; EPAMINONDAS, P. S.; SOUZA, A. L.; QUEIROZ, N.; SOUZA, A. G. Antioxidant activity of co-products from guava, mango and barbados cherry produced in the Brazillian Northeast. Molecules, v. 19, n. 3, p. 3110-3119, 2014.

BRAZIL. National Health Surveillance Agency. Resolution RCB $\mathrm{n}^{\circ}$ 272, of September 222005. 
Technical regulation for vegetable products, fruit products and edible mushrooms. Official Gazette [of] the Federative Republic of Brazil, Brasília, 2005.

BRAZIL. Ministry of Health. National Health Surveillance Agency. Normative Resolution $n^{\circ}$ 09, of December 11 1978. Technical Regulation on Identity and Quality of candies. Official Diary of the Union, Brasília, 1978.

CAMPOS, K. F.; MELO, A. B. P.; FONTES, C. P. M. L. Development of passion fruit and guava jam enriched with passion fruit peel flour. Revista Brasileira de Agrotecnologia, v. 5, n. 1, p. 99-102, 2015.

DIAS, M. V.; FIGUEIREDO, L. P.; VALENTE, W. A.; FERRUA, F. Q.; PEREIRA, P. P.; PEREIRA, A. G. T.; BORGES, S. V.; CLEMENTE, P. R. Study of processing variables for mass production of passion fruit peel (Passiflora edulis F. flavicarpa). Food Science and Technology, v. 31, n. 1, p. 65-71, 2011.

DIÓGENES JÚNIOR, A. C.; ALMEIDA, S. F.; FREITAS, P. V. C.; OLIVEIRA, E. N. A.; FEITOSA, B. F. Sensory evaluation and buy intention of soursop pastry. Food Hygiene. v. 33, n. 288/289, p. 250-254, 2019.

DUTCOSKY, S. D. Sensory analysis of food. 4 th ed. Curitiba-PR: Editora Universitária Champagnat, 2013. 531p.

GODOY, R. C. B.; WASZCZYNSKJ, N.; SANTOS, G. G.; SANTANA, F. A.; LEDO, C. A. S.; SILVA, S. O.; GARRUTI, D. S. Acceptance of banana jams elaborated with varieties Resistant to black-sigatoka. Revista Brasileira de Produtos Agroindustriais, v. 16, n. 2, p. 127-136, 2014.

GULARTE, M. A. Sensory analysis. Pelotas: University Publisher at the Federal University of Pelotas, 2009. 66p.

KATO, T.; RIBEIRO, K. P.; BORDONAL, V. C.; SILVIA, M. B. R.; OLIVEIRA, A. F.; SEIBEL, N. F. Quality evaluation of the fruit sweet products from Paraná North agrobusiness. Revista Brasileira de Produtos Agroindustriais, v. 15, n. 2, p. 173-182, 2013.

MELO, E. A.; ARAÚJO, C. R. Mango varieties "espada", "rosa" and tommy atkins: bioactive compounds and antioxidant potential. Semina: Ciências Agrárias, v. 32, n. 4, p. 1451-1460, 2011.
MOURA, R. L.; SILVA, A. P.; SILVA, F. G.; LIMA, S. P.; SOUZA, P. A. Evaluation of the physicalchemical quality of guava cream candy sold in Limoeiro do Norte-CE. Revista Verde de Agroecologia e Desenvolvimento Sustentável, v. 9, n. 3, p. 303-306, 2014.

ONIAS, E. A.; ROCHA, R. H. C.; LIMA, J. F.; ONIAS, E. A.; FURTUNATO, T. C. S. Organic 'Tommy Atkins' mango postharvest quality when treated with biofilms enriched by Spirulina platensis. Scientific, v. 44, n. 3, p. 286-293, 2016.

OLIVEIRA, E. N. A.; FEITOSA, B. F.; SOUZA, R. L. A. Technology and fruit processing: candies, jellies and jams. 1st ed. Natal: IFRN, p. 105-107, 2018.

OLIVEIRA NETO, J. O.; OLIVEIRA, E. N. A.; FEITOSA, B. F.; GERMANO, A. M. L.; FEITOSA, R. M. Use of banana peel in the elaboration of candy mariola type. Scientific, v. 46, n. 3, p. 199-206, 2018.

SANTANA NETO, D. C.; ALVES, A. M. A.; DOS SANTOS, A. F.; BEZERRA, J. M. Quality of banana mass candy added with functional components. Caderno Verde de Agroecologia e Desenvolvimento Sustentável, v. 4, n. 1, p. 1-6, 2014.

SILVA, F. A. Z.; AZEVEDO, C. A. V. The assistat software version 7.7 and its use in the analysis of experimental data. African Journal of Agricultural Research, v. 11, n. 3, p. 3733-3740, 2016.

SILVA, N. K. V.; SABINO, L. B. S.; OLIVEIRA, L. S.; TORRES, L. B. V.; SOUSA, P. H. M. Effect of food additives on the antioxidant properties and microbiological quality of red guava juice. Revista Ciência Agronômica, v. 47, n.1, p. 77-85, 2016.

SOARES, L. P.; JOSE, A. R. S. Bioactive compounds in mangoes pulp 'rosa' and 'espada' submitted to blanching and freezing. Revista Brasileira de Fruticultura, v. 35, n. 2, p. 579-586, 2013.

VALIM, A. P. W. Technician in Agroindustry. Fruit and Vegetable Technology. Pelotas: Federal Institute of Rio Grande do Sul, p. 23, 2011.

VIDAL, M. F.; XIMENES, L. J. F. Recent behavior of Northeastern fruit growing: areas, value of production and commercialization. Sectorial Notebook Technical Office for Economic Studies of the Northeast, n. 2, 2016. 